\title{
Piracy in Somalia: An Analysis of the Challenges Faced by the International Community
}

\author{
Amali Kartika Karawita \\ London School of Public Relations Jakarta (LSPR) \\ (email: amali.karawita@gmail.com)
}

\begin{abstract}
Piracy in Somalia is a phenomenon that has presented several challenges for the international community since the beginning of the $21^{\text {st }}$ century. Effectively formulating a plan of action against piracy requires the willingness of the international community to work together by implementing strong multilateral operations between countries and understanding the social and economic difficulties faced by Somalia, which has given rise to the endemic and its expansion throughout the region. Eradicating piracy means tackling the issue on land by confronting Somalia's extreme poverty and lack of economic opportunity as well as creating a comprehensive legal framework that will serve as a model to fight piracy. The objective of the present paper is to discuss the roots of piracy in Somalia and the cycle it created, as well as provide an analysis on the legal framework in place in order to judge its effectiveness on an international level. The method applied to lead this research is based on the analysis of reports from international bodies such as the UN and the ICC, as well as academic articles. The results have shown that piracy is the fruit of social, economic, and political issues that have enabled the phenomenon to spread and establish itself in the country.
\end{abstract}

Keywords:

maritime; piracy; international relations

\section{Introduction}

Maritime piracy has become a worrying issue, particularly in the pirate-infested region of the Gulf of Aden and the coast of Somalia, which poses great security threats to the thousands of ships sailing this route every day. The region holds strategic and economic importance due to the high maritime traffic. Every day, ships are exposing themselves to the increased risk of pirate attacks, endangering both the crews and the merchandise onboard. Several attacks were led off Somalia's coast, triggering international concern over safety. A well-known attack in March 2011 targeted the MV Sinar Kudus, which was the first Indonesian ship hijacked by Somali pirates. The ship and the crew were held captive for 46 days before being released after a ransom of $\$$ 4.5 million was paid (Ismunadi, 2011).

Somalia has attracted the attention of the international community after continuous pirate attacks in the region, triggering the main question on how to effectively deal with this issue. Somalia has a long history of conflict and unrest, which contributed to the ongoing chaos in the country and led to the development of piracy on its shores. The difficulty of finding an adequate long-term solution to fighting piracy has been the main problem the international community currently faces.

This paper aims to answer the following questions: what are the root causes of piracy in Somalia, and what are the solutions provided both onshore and off? Piracy is a crime 
taking its roots on land. It requires long-term solutions focusing on the creation of an honest, effective, and determined justice system and the commitment of the international community to eradicate this issue entirely (Murphy, 2008).

\section{Literature Review}

According to Murphy, piracy can be defined as a land-based crime. The solution to effectively fight piracy is to create honest and determined criminal justice system (Murphy, 2008). Treves (2009) also supports the idea that piracy has become a lucrative business in Somalia due to the political instability caused by the absence of an effective government as well as fighting between different factions for power. Furthermore, the author points out the inadequacy of the present legal framework on piracy to fight violent activities off Somali coasts. This inadequacy lies in the narrow definition of piracy according to international law and the willingness of seizing states to exercise their jurisdiction and prosecute pirates. International law allows actions to be taken against pirates, but it does not ensure that those actions are adequately taken. In "Securitizing piracy off the coast of Somalia," author Bilyana Tsvetkova argues that Somali piracy has become a regional and security issue due to its impact on international trade and human security. For this reason, the international community was enticed to become more proactive in the repression of piracy and to formulate solutions against this problem (Tsvetkova, 2009). Tsvetkova agrees with Murphy's claim that eradicating Somali piracy requires measures to interrupt the system supporting it inland (Tsevtkova, 2009). In his research on the political discourse and the policy response of the international community, Rothe and Collins (2011) concluded that the policies currently in place to deter piracy were largely inefficient. They ignored the root causes of piracy, such as the disorganized Somali society and the lack of a central authority.
The policies rather support global interests and state/corporate self-interests (Rothe \& Collins, 2011). The general consensus among academics is the international community's lack of interest and the inadequate policies in place to respond to the threat. The international community still remains wary of carrying out activities, especially onshore, to eradicate piracy successfully, preferring offshore military action instead. This weariness is due to the lack of a credible national government with whom to partner up (Affi, Elmi, \& Mohammed, 2015). By preferring to take actions offshore to secure international trade routes, the international community highlights its priority to protect foremost international trade before dealing with the root causes of piracy onshore (MartinezZarzoso \& Bensassi, 2012). The UN, the EU, the US, as well as other developed countries whose economy is supported on maritime commerce have suggested that the best approach to maritime piracy is through military means by the deployment of multinational naval warships that would restore security at sea. The weight of these international actors on the approach to piracy have overshadowed other anti-piracy approaches. For instance, the African Union has suggested re-establishing functioning governments (Tsabora, 2011).

\section{Background: Somalian Civil War}

The nature of the Somali conflict and the international context in which it has occurred since the 1980s has been constantly evolving. In its first phase, the conflict that started first as a civil war in the late 80 s slowly turned into conflicts between war lords in the 1990s before becoming a conflict of ideology with the rise of radical Islam in the 21st century (Bradbury \& Healy, 2010). The consequence of this conflict's evolution led to the disintegration of the Somali state and its inability to unite its government into a centralized authority later on. The state of lawlessness that befell Somalia in 1991 and the failure of the international community to 
rebuild and stabilize the country will enable piracy to develop and grow as a consequence.

\section{Somalia as a Failed State}

Menkhaus suggests that the categorization of Somalia as a failed state can be dated back from the 1970s following the Ogaden war with Ethiopia in 1977. The first signs of state failure were the collapse of Somalia's education system and state farm production in the 1970s. It was then followed by the weakening and dysfunction of most government institutions, rising tensions between clans, low salaries, and high levels of corruption, all of which consequently led to the expropriation of resources, especially foreign aid, for personal gains (Menkhaus, 2010).

The collapse of Somalia is linked to external and internal factors. Externally, Somalia's disintegration is the legacies of European colonization and the Cold War. Consequently, Somali society became increasingly militarized and divided (Loubser \& Solomon, 2014). The wars that followed with neighboring countries, such as Ethiopia, greatly weakened the country (Bradbury \& Healy, 2010). Internally, the conception of a centralized government holding authority created tensions within Somali culture based on a kinship system in which power is shared (Powell, Ford, \& Nowrasteh, 2008).

From 1969 to 1991, Somalia was under the harsh regime of Mohamed Siad Barre. Barre's dictatorship led to growing resentment amongst the population and cultivated rivalries between clans. The repercussions of Barre's politics have contributed to the inability of Somali clans to form a unified government (Menkhaus, 2007).

The fall of Barre's regime was accelerated by the end of Cold War and the decline of Somalia's strategic importance, which then lead to the diminution of foreign aid. For over 15 years, foreign aid had sustained the extensive patronage system and civil service to stabilize the regime (Menkhaus, 2007). By
January 1991, the insufficient resources and the discontentment toward the government caused Barre's removal from power. Somalia was the theater of violent clashes for power and control between clans. Warlords began taking control of Somalia's fractured territory and competed against each other to extend their domination (Bradbury \& Healy, 2010, p.10). Somalia formally reached its collapse by May 1991 (Bradbury \& Healy, 2010).

\section{International response to Somalia's collapse}

In response to Somalia's collapse, the United States, with the support of the United Nations, launched a multinational force in December 1992 called "United Nations Operation in Somalia" (UNOSOM) in the hopes of restoring order and responding to security challenges posed by the collapsed Somali state through military and humanitarian intervention (Bradbury \& Healy, 2010). From 1992 to 1995, UNOSOM aimed to revive important governmental functions and restart the economy to increase security. Humanitarian operations, which consisted of food and water distribution, were also actively conducted. However, UNOSOM was highly criticized for its failure to end conflicts and disarm factions that hindered the peace process. UNOSOM instead contributed to conflicts in Somalia by reinforcing the warlord power structures and allowing the proliferation of armed groups. As a result, UNSOM was forced to withdraw its forces. This event marked the disengagement of Western powers (Bradbury \& Healy, 2010). On a regional level, after the retreat of UNOSOM, the Intergovernmental Authority on Development (IGAD) became involved as the main actor to resolve the Somali conflict by promoting political dialogue and restoring stability. However, IGAD faced many obstacles in the pursuit of its mandate such as the lack of political will from Somali clan elders who were reluctant to share power, financial constraints, weak armies, and the lack of logistical support 
to continue its operations (Hearn et al., 2014). Shortly after, IGAD was replaced by the African Union Mission to Somalia (AMISOM) in 2007 and is currently operating in the country. AMISOM focuses on state-building and peacebuilding operations. Its main objective is to establish security by increasing the territorial control of the Federal Government of Somalia (FGS). Its serves as a force to impose the legitimacy of the FGS and thus solve the issue of state failure plaguing the country since 1991 (Williams et al., 2018). The mission has also been actively engaged in military operations aimed at dismantling terrorist groups (Williams et al., 2018). Although the terrorist threat is still present, AMISOM was able to increase security, which has allowed Somalia to engage in the political process for reconciliation and transfer some security responsibilities to Somali forces, thus reviving important components of a well-functioning nation. However, just like IGAD, AMISOM still faces many obstacles in conducting its operations, such as the lack of resources and capabilities to successfully accomplish its mandate (Williams et al., 2018). Its planned withdrawal in 2021 threatens stability and territorial gains (Faleg, 2019). During the years following the collapse of Barre's regime, the US became heavily involved in Somalia through UNITAF and Operation Restore Hope, which was set to help the humanitarian catastrophe faced by the Somali people with the help of military force. The result was remarkably successful. UNITAF secured ports and airfields, helped humanitarian organizations safely reach their destination, and they opened up communication lines. Unfortunately, the support provided by UNITAF was subjected to conflicts between the military and the humanitarian community (Kennedy, 1996). This issue appears again with the establishment of UNSOM in 2017 and the opposition of humanitarian groups, which feared the politicization of humanitarian activities (Action Against Hunger, 2015).
Civil society organizations (CSO) have also played the important role of filling in the gaps left by the collapse of Barre's regime. These non-state actors participated in efforts of peace-building by promoting dialogue, reconciliation, and rebuilding trust in a polarized society. CSOs were facing many difficulties in implementing themselves as a unifying force due to institutional issues, lack of resources, organizational weaknesses, and internal disputes (Osman, 2018). Another major issue is the lack of non-partisan CSOs. Associations and NGOs often followed clan lines, which is not surprising given the context of Somalia's society based on kinship (Tiilikainen \& Mohamed, 2012). Many criticisms were formulated against the local and international NGOs that have been using war for their own benefits. The success of these different initiatives, although not negligible, are limited due to financial issues to conduct and maintain operations, identity politics that hinder the unification of the Somali people and the establishment of government legitimacy, as well as the issue of extremism relating to the influence of terrorist groups.

\section{The Rise of Islamist Movements}

The failure of the international community to find a suitable solution to the Somali problem provided a fertile ground for the emergence of Islamist extremists seeking to create an Islamic State. Since 1991, local terrorist organizations, such as Al-Itihaad, have actively tried to establish an Islamic State in Somalia by developing indirect political control through the infiltration of local administrations (International Crisis Group, 2002). Al Qaeda has also developed its network in Somalia by supporting local Islamic groups with training and logistics. The unguarded coasts of Somalia have sparked concern among Western countries, which believed that Al Qaeda was using Somalia as one of the group's hidden bases for its land and maritime operations. 
Another concern raised by the international community was the possibility of collusion between terrorists and pirates in the region (Nelson, 2012). This concern is mainly motivated by the assumption that terrorists could be inspired by the pirates to conduct maritime operations against ships (Murphy, 2008) or use piracy as a means to finance their land operations (Brookes, 2009). However, today, there is no conclusive evidence supporting this claim (Murphy, 2008).

Nevertheless, the lack of an effective government in Somalia provides ground for criminal activities to take place. The historical roots of the Somali conflicts have given rise to the phenomenon of piracy by creating an adequate setting for such activity to develop over time. Piracy in Somalia has thrived on two decades of extreme violence, which have had devastating economic, political, and social effects on the population and nation at large.

\section{Failed State and the Rise of Piracy}

In this context, Somalia's failure to form a stable government since 1991 led to the development of piracy as a response to the absence of a central authority able to control the territory and provide basic needs to the population. One of the main consequences of a state's disintegration is the inability to perform security tasks. This meant that Somalia's $3,330 \mathrm{~km}$ coastline, the longest in continental Africa, as well as its borders were not patrolled (Tharoor, 2009). Therefore, foreign fishing ships were able to take advantage of the political situation. The absence of an effective authority over Somali territorial waters led foreign fishing ships to plunder Somali's fish stocks (Husein, 2010). The UN has estimated that the cost of illegal fishing in Somalia reached $\$ 300$ million each year (Tharoor, 2009). The Somali fishing industry has always been a small-scale industry, which in terms of their fleet, lacked new technologies and modern boats compared to foreign fleets (Tharoor, 2009). With their own rudimentary equipment, local fishermen could barely compete against the bigger and more modern foreign ships. In addition to illegal fishing, Somali waters have become the dumping ground for industrialized countries of hazardous waste since the early 1980s.

The 2005UNEP environmental assessment on Somalia reported that the waste dumped along Somalia's coasts comprises of highly toxic waste dangerous to the environment and the health of local populations (Tharoor, 2009). Most of this waste was not disposed of adequately according to international measures. The 2004 tsunami led to the contamination of the drinkable water sources for the population (UNEP, 2005). To this day, the dumping of hazardous waste has had devastating impacts on the local populations, who have experienced health problems such as respiratory infections, skin diseases, child disfigurement, and even death (UNEP, 2005). It is estimated that the cost of dumping toxic or radioactive waste off the Horn of Africa for European companies is around $\$ 2.50$ per ton instead of $\$ 250$ per ton if these companies disposed of the waste properly and legally in Europe (Tharoor, 2009).

As a response to the environmental and illegal fishing threats, Somali fishermen were forced to defend their waters and insure their fishing expeditions (Tharoor, 2009). In the early 90s, the fishermen took up arms against foreign ships. At the beginning of maritime piracy, trawlers intercepted boats without licenses and paid a small amount to the interceptors to conceal the illegality of their activity. People saw in this practice the possibility to make money. Soon, fishermen joined hands with militias and unemployed youth to hijack ships (Raunek, 2016). Pirates were able to create a business centered on ship hijacking and ransoming, which consequently led their interest to bigger catches with higher value (Tharoor, 2009). Although the initial motive of these fishermen was the protection of their 
waters, the economic gains from intercepting foreign ships rapidly took over.

\section{Piracy, An Economic Phenomenon}

Somalia's economic situation helped foster the development of piracy. As a result of the civil unrest, the Somali economy was completely destroyed. The absence of a central government to regulate and articulate coherent economic policies aggravated the country's economy. Poverty in Somalia is endemic. Over 12 million people are living below the international poverty line, at $\$ 0.19 /$ day in 2017 (World Bank, 2017). The unemployment rate is one of the highest, accounting for $67 \%$ of a young population in which $70 \%$ of the population is under the age of 30 (UNICEF, 2017). Inequality is high as economic growth happens in the city, accentuating the gap between urban and rural areas (World Bank, 2017). The absence of a stable government providing services to the population means that the private sector has become the main provider of these services. This privatization has led to the development of an unregulated economy in which piracy and other criminal activities are booming freely (Menkhaus, 2010).

Piracy became a particularly lucrative business that generated $\$ 415$ million in ransom money between 2009 and 2010 (Bowden et al., 2010). So as long as Somalia's economy does not improve, piracy will continue to thrive. In a country where poverty is rampant, piracy offers an alternative way to make a living, which attracts young Somali men. Piracy is viewed as an economic opportunity to improve people's livelihoods. Pirates able to strike a good ransom deal can radically change their lives. This practice offers young men the opportunity to integrate the economic elite of the country (Osei-Tutu, 2011). Many build lavish houses, buy new cars, drugs, prostitutes, guns, and marry the most beautiful girls, thus giving them a taste of the high life (Hunter, 2008).
Maritime piracy is able to grow on the gap left by the central state. It has revitalized local economies. Somali culture highlights the importance of sharing. Those who are wealthy are expected to share their resources with other members of the clan as a moral obligation (Shortland, 2012). The profits of piracy are distributed among the community. Roughly $30 \%$ goes to the hijackers, $10 \%$ to the local community elders and officials, while $20 \%$ of profits go to financiers and the last $10 \%$ to the sponsors (Kellerman, 2011).

On the other hand, piracy has brought significant development and infrastructure to the county and its population. For example, the inland city of Garowe has registered a wide growth from 2002 to 2009, with satellite images showing light industrial and commercial development (Shortland, 2012). A number of hotels have popped up, destined for a rich clientele most likely linked to pirates. Therefore, money earned through piracy has brought some contributions to the fast growth of Garowe, designating the city as the center for the pirates' operations (Shortland, 2012). Piracy money is mostly spent inside Somalia, especially in the urbanized inland cities like Garowe.

\section{Corruption of Somali Officials}

The spread of piracy along the coast of Somalia, as well as the creation of strong base camps in urban cities, would not be possible without the high levels of corruption usually affecting failed states. Corruption is one of the elements undermining the formation of a stable authority in Somalia (Anti-Corruption Resource Centre U4, 2012). The country is ranked as one of the world's most corrupt countries, obtaining in 2011 a score of 1 on a scale of 0 to 10, 10 being the highest level of cleanliness (Anti-Corruption Resource Centre $\mathrm{U} 4,2012)$.

Corruption prevents economic growth and development (Ahmad, Ullah, \& Arfeen, 
2012). In Somalia, corruption is even more exacerbated by the elite who compete for power and access to resources (Ahmad, Ullah, \& Arfeen, 2012). In a poverty-stricken system, corruption provides the perspective to increase the income, providing people with additional revenue which is not negligible in Somalia (Leslie, 2014).

Corruption enables pirates to pursue their multimillion-dollar business with impunity. The absence of an effective government with sufficient resources to pay security forces gave strong incentives for bribery and extortion (Anti-Corruption Resource Centre, 2012). For example, armed militias imposed fees and staff taxes to UN agencies and non-governmental organizations (NGO) to access, monitor, and manage these agencies' activities with the aim to divert humanitarian assistance (Member of the Monitoring Group on Somali and Eritrea, 2012). Immigration services, airports, customs, and ports are also affected. A large part of official corruption is conducted at the Mogadishu port and other ports in the Puntland area, where local officials are accepting bribes from pirates (Tharoor, 2009). The telecommunication sector has been particularly affected by corruption due to its importance for piracy. Telecommunication companies often pay undeclared fees to officials to protect them (Anti-Corruption Resource Centre, 2012). In areas where piracy is virulent, like Haboyo, hijacked ships are kept several miles from the coast. Telecommunication service is needed to ensure that the ships are guarded, supplied, and that the hostages are alive. Pirates use the Internet to evaluate ransoms (Shortland, 2012). Furthermore, pirates need to access information, especially from government and port officials, in order to conduct their operations (Gilpin, 2009). Bribing officials guarantee the continuous access of ship information (Gilpin, 2009).

Corruption is intrinsically linked to money laundering (OECD, 2017). Organized pirate syndicates operating in Dubai have been laundering money acquired through ransoms. People incriminated in these illicit operations include businessmen from Somalia and the Middle-East mainly. These syndicates play a major role in the development of piracy off the Somali coast, especially by getting access to new technologies useful for hijacking and tracking ships (Sengupta \& Howden, 2009).

\section{Piracy, A Response to Somalia's Social Context}

The economic degradation that followed the disintegration of the Somali state severely impacted the population, allowing piracy to thrive in such an environment. The two decades of civil unrest led to severe social consequences, such as widespread poverty, hunger, and the displacement of the population. The collapse of the state gave rise to conflicts between clans and factions for control over territories and resources essential for survival (Bradbury \& Healy, 2010). The scarcity of resources only fueled more violence. Consequently, it forced 1.5 million people to flee Somalia from December 1991 to March 1992 and it displaced over 2 million people (Bradbury \& Healy, 2010).

Furthermore, the Horn of Africa is particularly vulnerable to food shortages. Food security is measured by the availability, access, stability, and the utilization of food (Stringer, 2016, pp.11-18). In Somalia, food shortages were accentuated by the ongoing conflict, making it difficult for humanitarian operations to take place. It also hindered agricultural production. This led to a substantial increase in the price of food for people who could barely afford enough to sustain their existence (Terefe, 2012).

The combination of these several social and economic issues has contributed to the implementation of piracy. When taking into consideration that a single pirate hijack can lead to a ransom anywhere between $\$ 500,000$ and $\$ 3$ million (with individual profit going up to $\$ 15,000$ in a country where poverty is rampant 
and economic opportunities are low) it becomes understandable why piracy has been such an attractive business for young Somalis (Gilpin, 2009). This practice guarantees their survival in face of misery.

In order to defeat piracy, it is important to address the issues Somalia faces as a failed state. As Murphy said, piracy is foremost a land-based crime as it arises from economic and social problems. The root of these problems resides in the non-existence of a functional state that can perform its duties and provide opportunities and security for its inhabitants.

\section{Addressing Piracy Offshore}

The Holes in the Application of the Legal Framework on Piracy

The United Nations Convention on the law of the Sea (UNCLOS) is the main basis upon which the legal framework FOR piracy is set. UNCLOS reflects customary international law which binds all states, parties, and nonparties (Marciniak, 2012). Piracy is defined in article 101 of UNCLOS as:

(a) any illegal acts of violence or detention, or any act of depredation, committed for private ends by the crew or the passengers of a private ship or a private aircraft, and directed: (i) on the high seas, against another ship or aircraft, or against persons or property on board such ship or aircraft; (ii) against a ship, aircraft, persons or property in a place outside the jurisdiction of any State;

(b) any act of voluntary participation in the operation of a ship or of an aircraft with knowledge of facts making it a pirate ship or aircraft;

(c) any act of inciting or of intentionally facilitating an act described in subparagraph (a) or (b).

This definition presents certain limitations. The conditions for an act to qualify as piracy are acts committed for private ends, involving at least two ships and taking place on the high seas (Chalk, Smallman, \& Burger, 2009). This definition excludes many acts of piracy occurring on territorial seas. Furthermore, the definition stresses on an act committed for private ends meaning that an act motivated by political ends does not qualify as piracy under UNCLOS (Kao, 2016).

In the case of piracy in Somalia, the main issue regards article 100 of UNCLOS which states:

"All States shall cooperate to the fullest possible extent in the repression of piracy on the high seas or in any other place outside the jurisdiction of any State."

Piracy is a crime that falls under international jurisdiction. Every state has the responsibility to arrest any person participating in piracy. UNCLOS provides a legal basis to prosecute these acts; however, this framework depends on whether nations have sufficient national laws and willingness to bring pirates to trial (Chalk, Smallman, \& Burger, 2009). The problem in the Horn of Africa is that captured pirates were often released without facing justice. Somali pirates are unlikely to be tried in Somalia due to the absence of an effective government (Warner, 2013). The seizing states are usually reluctant to use such extensive powers by prosecuting and bringing arrested pirates to their courts, as this represents a considerable burden to the seizing state. If Somali pirates were to serve their sentence in another country, their return to Somalia would be impossible. Moreover, the length of the detention before being charged or receiving legal assistance are possibly violating human rights laws (Treves, 2009; Warner, 2013; BBC, 2011). This demonstrates the clear hole on how to deal with captured pirates (Treves, 2009). As a result, effective international actions were slowed down off the coasts of Somalia, which led pirates to be released without facing any criminal charges (Treves, 2009). 


\section{International Cooperation as A Solution Against Piracy}

Effectively defeating piracy in Somalia demanded extensive international cooperation and self-investment from different navies, which today represents a remarkable degree of collaboration between countries (Chalk, Smallmaen, \& Burger, 2009). The international community agreed to adopt a common and global approach regarding piracy in order to secure the region. Several joint actions were set up. States use naval power to counter the threat.

In 2008, the European Union (EU) launched a counter-piracy operation named EU NAVFOR-Atalanta along the coasts of Somalia (European Union Naval Force Somalia, 2015). The different countries taking part in this operation provide navy vessels, maritime patrols, and reconnaissance aircraft, as well as military and civilian staff (European Union Naval Force Somalia, 2015).

This operation enables EU NAVFOR to arrest suspected pirates and seize all objects onboard suspected ships. People apprehended during the operation can be prosecuted by any EU members, and by neighboring nations where the pirates are caught, or a third-party State (European Union Naval Force Somalia, 2015). A transfer option is given for states who seized pirates and who do not want to exercise their jurisdiction. Pirates can be transferred to any member-state or third-party state willing to prosecute them (Treves, 2009). Moreover, the operation does not only aim at tracking down and bringing pirates to trial, but it also aims at destroying the business of piracy especially its financing. The EU's action works on sharing information with Interpol and EUROPOL (European Union Naval Force Somalia, 2008).

Since 2008, Operation Atalanta has been highly successful. It has effectively helped drop the number of pirate attacks before they happen. To illustrate this last point, in January 2011, 736 people were taken hostage and 32 ships were captured by pirates. By October
2016, no persons nor ships were detained by pirates, showing that Operation Atalanta has contributed to the prevention and deterrence of acts of piracy in Somalia by notably providing protection to ships in the "High Risk Area", which is an area where there is a higher risk for piracy to happen and in which selfprotective measures are most likely required (International Maritime Organization).

Furthermore, Operation Atalanta has worked closely with several regional governments, such as Kenya, the Seychelles and Mauritius, for the transfer of presumed pirates with the perspective of their persecution and conviction, thus illustrating the EU's determination to defeat piracy by applying sanctions in collaboration with other governments thus strengthening the legal framework in place and patrolling the Gulf of Aden and the Indian Ocean as well as conducting reconnaissance and surveillance missions (European Union Naval Force Somalia, 2015).

The EU's engagement against piracy has also led EU NAVFOR to conduct land raids in Somalia after Operation Atalanta was expanded to include land targets. With the support of the Somali transitional government, the first raid was led near the port of Haradhere, a wellknown pirate base. The goal was to destroy onshore safe havens for pirates and deprive them of logistics to pursue their operations (BBC, 2012).

Just like the EU NAVFOR and its Operation Atalanta, other joint measures have been instituted like the CTF-151, a multinational task force established to coordinate international maritime patrols in the Gulf of Aden. Several states like China, Russia, and South Korea have been sending navy ships into the region (Chalk, Smallman, \& Burger, 2009). These measures were given more weight thanks to Resolutions 1816, 1846, and 1851 passed by the Security Council which urge states to take necessary actions to stop pirate attacks coming from 
Somali territorial waters (Chalk, Smallman, \& Burger, 2009).

Resolution 1851, adopted in December 2008, encouraged nations and regional organizations fighting against piracy to put in place: " $[\ldots]$ an international cooperation mechanism to as a common point of contact between and among states, regional and international organizations on all aspects of combating piracy [...] off Somalia's coast," (United Nations Security Council, Resolution 185, 2008, p.3).

The following year, the Contact Group on Piracy off the Coast of Somalia (CGPCS) was established. The CGPCS serves as the coordinator between the different navies involved in counterpiracy in the Gulf of Aden, the Internationally Recognized Transit Corridor and the Somali basin. Through concrete steps, the group works actively on mitigating piracy threats by giving counter-piracy trainings, promoting the Best Management Practices (BMP) (which are counterpiracy measures for ships), and also promoting ways to strengthen self-protection capabilities (Oceans Beyond Piracy, n.d.)

Compared to the EU NAVFOR, the CGPCS holds the role of spreading public and diplomatic information on several aspects of piracy, thus raising awareness on the threat posed by this issue (Oceans Beyond Piracy, n.d.). Furthermore, in 2009, the CGPCS launched a mission in East Africa and in the Gulf of Aden which aimed to assess the regional capabilities of counter-piracy. The final report highlighted the need to bring support to solutions against piracy, which include strengthened penal and judicial legislations and involving the media and the communities in the fight against piracy (Oceans Beyond Piracy, n.d.). More importantly, the report highly recommends the further implementation of the Djibouti Code of Conduct upon which counter-piracy measures depend (Oceans Beyond Piracy, n.d.).

Naval actions alone will not solve the issue of piracy in Somalia; it can only deter its operations. As such, a global and comprehensive approach by nations needs to be adopted and the legal framework against piracy needs to be strengthened to reaffirm the international community's will to end piracy.

\section{The Djibouti Code of Conduct}

As emphasized by the CGPCS, the key to defeating piracy lies on the development of a regional approach regarding the issue. The Djibouti Code of Conduct focuses on localized actions to counter piracy in the region as opposed to actions led on water by naval forces (Kraska \& Wilson, 2009). This initiative, which is a legally non-binding instrument, reflects the international community's will and determination to erase piracy. The next important step lies in capacity-building which includes the reinforcement and the consolidation of national institutions. The parties to the Djibouti Code are committed to sharing and reporting information to information centers as well as national focal points and prohibit ships suspected of piracy (Kraska \& Wilson, 2009). Moreover, nations also engage in arresting and prosecuting pirates. The objective is to empower a state's law enforcement forces as well as to enhance national legislations on piracy to meet the need of the state's law enforcement and judiciary system (Oceans Beyond Piracy, n.d.). The present Code of Conduct takes into consideration international cooperation in the scope of maritime security operations as well as the coordination of security operations through the three maritime information-sharing centers (Kraska \& Wilson, 2009). By reinforcing regional capacities by notably developing the Somali and other East African countries coastguards and providing a regional training program with other international organizations, such as NATO and the EU, the Code aims at creating a first wall against piracy (Oceans Beyond Piracy, n.d.).

The Djibouti Code of Conduct is an important instrument supplementing the existing legal framework regarding piracy. 
The objective is to make this framework more effective in combating piracy. For this reason, the Code of Conduct stresses parties, such as Saudi Arabia and Egypt, to help provide resources for East African countries in order to develop the capabilities of the region. The main issue faced by many of these countries is the lack of resources (Muli, 2011). It has become apparent that a big disparity from a technological standpoint exists between East African countries that clearly lack maritime security capacity and big naval forces like the United States (Kraska \& Wilson, 2009). It becomes difficult to work when such differences remain between the countries, because piracy is an international issue and the only way to defeat it is through multilateral cooperation and the development of countries like Somalia in terms of maritime capacity. The Jeddah Amendment adopted in 2017 revised the Djibouti Code by broadening its scope to include a range of illicit maritime activities such as human trafficking and illegal, unreported, and unregulated fishing (IUU) (IMO, 2019). In particular, the amendment shifted the traditional state security perspective to human security by recognizing the importance of the "blue economy" in promoting sustainable economic growth, employment, and stability (Brits \& Nel, 2018). Local economies would benefit from sustainable fishery management and prevention of maritime crimes. The Jeddah Amendment is the first agreement to paint a bigger picture on maritime issues in the region (Menzel, 2018). Its success only depends on the willingness of countries to implement the new measures. The amendment is a small step towards progress. It offers a newly perspective on the issue; however, it is still very restrictive, focusing on national security rather than human security as a solution to maritime issues in the region (Brits \& Nel, 2018)

Although the Djibouti Code offers a great advancement in the domain of counter-piracy and cooperation, the question of whether or not the Code can reach its objectives is debatable. It is primarily a non-binding agreement, which is apolitical and operating mostly on a technical level, showing that, in reality, the level of political support is quite weak (Bueger \& Saran, 2012). Moreover, there is no guarantee that countries in the region will successfully cooperate with each other, especially knowing the history of national rivalries and disputes in the region. Bueger \& Saran (2012) The second flaw of the Djibouti Code lies in its over-ambitious agenda, which aims at creating a trans-regional solution by bringing together African and Gulf nations but excluding countries like India and Pakistan, which are two important maritime powers active in the domain of counter-piracy, due the operational field of piracy groups in the Indian Ocean (Bueger \& Saran, 2012).

However, the implementation of the Djibouti Code is a big step forward in the fight against piracy. It is an important step in the development of regional capacities (Geiss \& Petrig, 2011). It is through the development of a regional infrastructure that piracy can be addressed in the long term. The workshops and training offered, as well as the culture of information-sharing and communication, are the main keys the Djibouti Code highlights in order to advance a functional counter-piracy policy (Bueger \& Saran, 2012).

\section{International Measures and its Impact on Piracy}

The different measures taken since 2008 have had a positive impact on the number of pirate attacks near the coasts of Somalia, showing a sharp decline. According to the International Maritime Bureau, they registered only 15 attacks off the coasts of Somalia in 2013 compared to the 75 incidents in 2012 and 237 incidents in 2011, which was the peak of Somali piracy (ICC, 2013). In 2016, no successful attacks off Somalia were registered (Patinkin, 2017). More recently, a new report published 
by the ICC International Maritime Bureau reveals a further decline of piracy attacks. From January to June 2017, 87 attacks have been reported compared with 97 incidents worldwide, showing a decline when compared to the same previous period, where 97 incidents were reported. Piracy off Somalia's coasts made up only 5 of these incidents (ICC, July 2017).

This successful decrease in attacks have been attributed to the efforts of the international community, especially through naval operations, mitigation measures, and the determination of the international community to defeat the threat posed by piracy in Somalia. Although the number of incidents has been low since 2012, the region is not completely free of pirates, and continued efforts will need to be made to assure that the Gulf of Aden remains safe.

\section{Addressing Piracy Onshore}

The main key to addressing the issue of piracy in Somalia is to create a peaceful and stable environment to enable the process of peace-building and state-building. The Somali Compact is the result of a process determining Somalia's priorities for three years (2014-2016). This compact has included a comprehensive approach to the main peace and state-building goals, which include rebuilding trust and dialogue among Somalis. However, progress is still to be made regarding engagement and dialogue with Somalis as well as the coherence between humanitarian and development efforts in order to produce long-term results (Manuel et al., 2017). Along with state-building efforts, there is a clear need to establish the legitimacy of the government in order to restore stability in the country (Hearn et al., 2014). Thus, there is the need to involve and actively engage Somali people. The challenge is to create a unified voice and promote cooperation in order to create democratic political institutions and engage in peace mediation and capacity-building in health and education sectors (Tiilikainen \& Muhamed, 2012).
As one of the main components of the Somali Compact, stability calls for initiatives such as the Transition Initiatives for Stabilization+ (TIS +) to increase stability and further the participatory process in order to promote good governance and community cohesion at district and communal levels. These initiatives advocate for the restoration of dialogue between communities through art, culture, and sports activities to enable the population to heal from the trauma of the war and prevent vulnerable classes to fall into extremism (USAID, 2019).

Stability also goes along with economic initiatives to assure the long-term reestablishment of the Somali Government. The lack of economic recovery and employment opportunities reinforce the cycle of violence and conflicts that have driven many Somalis to engage in piracy as an alternative for living (Menkhaus, 2004). State failure results in the collapse of the economy and economic collapse creates state failure. The goal is to break this vicious cycle (Menkhaus, 2004). Creating economic opportunities will ultimately improve the livelihood of the population by creating jobs and increasing production and income. Economic programs like the Growth, Enterprise, Employment and Livelihood program (GEEL) aim to integrate Somalia into the global economy, thus reviving the local economies (USAID, 2019). Change is caused by the evolution of political and economic interests of key actors in Somalia. For example, UNOSOM has had an important economic presence in Somalia, which has produced economic opportunities such as procurement and construction contracts, property rentals, and currency exchange. Economic actors were motivated by the potential economic gains that led to a shift to more legitimate commerce and services (Menkhaus, 2004).

The revitalization of the economy will demand human capital. Education will be essential to support economic growth. The 
Somali population is particularly young, around $40 \%$ of Somalis are between the age of 6-18; this demographic will become important contributors to the economy in the years to come. Education will enable younger generations to learn skills and knowledge. The challenge is to overcome low school enrollment and the lack of educational facilities and qualified teachers in the country that have suffered due to civil wars (World Bank Group, 2019).

\section{Conclusion}

The case of piracy in Somalia hasillustrated the importance of defeating piracy by resolving Somalia's internal problems and strengthening its criminal justice system. Piracy developed as a consequence of the disintegration of the Somali state. The population was severely affected by the two decades of conflict that followed the collapse of the Barre regime in 1991. Violence became an integral part of life for the Somali people. With no functioning government able to perform state duties, such as assuring security on land and sea, Somalia became the victim of plundering from foreign ships and the dumping ground of toxic waste, which ultimately triggered fisherman to take up arms and engage in acts of piracy as a way of survival due to the gross lack of economic opportunities and the vicious circle of poverty and hunger that kept creeping up. This setting enabled piracy to flourish and impose its roots deeply within Somali society.

Understanding the background history of Somalia is the main key to addressing the issue of piracy. Piracy takes its roots on land, which means that in order to defeat piracy it is important to work on a solution on land by confronting the economic and social issues present in Somalia and articulating long-term action plans to revitalize Somalia's economy as well as assuring humanitarian aid to the country to fight poverty and famine and continue the process of state-building in order to reinforce and strengthen the authority of the present institutions to reestablish the rule of law. Somalia's transitional government needs to actively fight corruption, which enabled piracy to spread with impunity throughout the country as well as work actively to break down the underground economy created by this business with the help of the international community, since piracy is a transnational threat.

The case presented the importance of an effective and strengthened justice system willing to eradicate this problem. Even though piracy is a crime that falls under universal jurisdiction, the reality shows that states are often unwilling to assume such extended rights or are unable to prosecute suspected pirates due to inadequate national legislation or the lack of law enforcement, as was the case with Somalia. From the beginning, the international regime against piracy lacked efficiency in dealing with captured pirates, which led to the unwillingness of nations to bring charges against pirates. This lack of efficiency hindered effective international actions to take place.

The trigger, which led to the change of the international community's attitude, was the surge of Somali pirate attacks in the Gulf of Aden from 2008 to 2012. The global approaches adopted by the international community showed its determination to eradicate piracy in Somali waters. This approach pushed for multilateral cooperation between nations. Operations led by EU NAVFOR, CT-151, and the establishment of the CGPCS are signs that the international community will no longer tolerate acts of piracy. Naval operations, like Atalanta, send a clear message to pirates that the stance on piracy has changed. It is a clear example of a determined policing effort. The international community is taking a hard line in the repression of this crime. Since cooperation means that information-sharing is necessary in order to dismantle the business model of piracy and track down the people behind it, honest 
communication between the different parties to the fight are required. Finally, as demonstrated by the Djibouti Code of Conduct, naval operations are not enough to stop pirates; it is important to develop the maritime capacities of countries like Somalia, in collaboration with other international organizations that should be on the front line in the fight against piracy. This case also illustrated the importance of social and economic initiatives in order to restore stability in the Somali society for the peace-building and state-building process to begin. These onshore initiatives are aimed at increasing the well-being of the society by providing durable and viable living alternatives for young Somali citizens. The approach of the international community has begun to shift to an approach based on human development instead of only focusing on military measures.

The effectiveness of these different measures and initiatives has led to the decrease of pirate attacks in Somali waters between the 2011 peak of piracy and 2017. The efforts made to address the issue of piracy should be maintained and strengthened. The position of Somalia has revealed the importance of bringing the fight both on land and at sea. Piracy is more than just attacks against ships; it is the consequence of economic and social problems and the lack of an efficient government. The threat of piracy, although greatly reduced, is still present; the main task is to control it.

\section{References}

Action Against Hunger. (2015, August). Consequence of the structurally integrated UN Mission in Somalia on principled humantiarian action and access to population in need. Retrieved from https://www. actionagainsthunger.org/blog/somaliaeighteen-months-after-establishmentunsom-action-against-hunger-deeplyconcerned-about

Affi, L.A., Elmi, A., \& Mohamed, S. (2015). Avoidinf Somalia: What prevents onshore solutions to piracy? Global Affairs, 1(3), 305314. doi: 10.1080/23340460.2015.1078576

Ahmad, E., Ullah, M. A., \& Arfeen, M. I. (2012). Does Corruption Affect Economic Growth. Latin American Journal of Economics, 49(2), 277-305. doi: 10.2307/41959246

Anti-Corruption Resource Center U4 expert answer. (2012, July 13). Overview of corruption and anti-corruption in Somalia. Retrieved from https://www.google. $\mathrm{com} / \mathrm{url}$ ? sa $=\mathrm{t} \& \mathrm{rct}=\mathrm{j} \& \mathrm{q}=\&$ esrc $=\mathrm{s} \& \mathrm{sou}$ rce $=$ web \&cd $=1 \&$ ved $=0$ ahUKEwjmno SN2PXYAhXGe7wKHR37CU8QFgg oMAA\&url=http $\% 3 \mathrm{~A} \% 2 \mathrm{~F} \% 2 \mathrm{Fwww}$. u4.no\%2Fpublications \%2Foverview-ofcorruption-and-anti-corruption-in-somal ia\%2Fdownloadasset $\% 2$ F2894\&usg=AOv Vaw1wL4nRiFU0L85ugGO3G4Xf

BBC. (2012, May 15). Somali piracy: EU forces in first mainland raid. $B B C$ News. Retrieved from http://www.bbc.com/news/worldafrica- 18069685

BBC. (2011, January 25). Q \& A: What do you do with a captured pirate? BBC News. Retrieved from https://www.bbc.com/ news/world-africa-11813168

Bowden, A., Hurlburt, K., Aloyo, E., Marts, C., \& Lee, A. (2010). The economic cost of maritime piracy. Retrieved from http:// oceansbeyondpiracy.org/sites/default/ files/attachments/The $\% 20$ Economic $\% 20$ Cost $\% 20$ of $\% 20$ Piracy\%20Full\%20Report. pdf

Bradbury, M. \& Healy, S. (2010). Endless war, a brief history of the Somali conflict. Accord, 21, 10-14. Retrieved from https://rcservices-assets.s3.eu-west-1.amazonaws. com/s3fs-public/Whose_peace_is_it_ anyway_connecting_Somali_and_ international_peacemaking_Accord_ Issue_21.pdf

Brits, P. \& Nel, M. (2018). African Maritime security and the Lomé Charter: Reality or dream?. African Security Review, 1-20. doi: 10.1080/10246029.2018.1546599 
Brookes, P. (2009). The Challenges of Modern Piracy. In M. R. Haberfeld \& A. von Hassell (Eds.), Modern Piracy and Maritime Terrorism: The Challenge of Piracy for the 21st Century (pp. 177-203). Dubuque, IA: Kendall Hunt.

Bueger, C. \& Saran, M. S. (2012, August 18). Finding a regional solution to piracy: Iet.s the Djibouti Process the answer? [Web log post]. Retrieved from http://piracy-studies. org/finding-a-regional-solution-to-piracyis-the-djibouti-process-the-answer/

Chalk, P., Smallman, L. \& Burger, N. (2009). Countering piracy in the modern era: Notes from a RAND Workshop to discuss the best approaches for dealing with piracy in the 21st century. California : RAND Corporation.

European External Action. (2013). The Somali Compact. Retrieved from https://eeas. europa.eu/sites/eeas/files/20130916_the_ somali_compact.pdf

European Union Naval Force Somalia Operation Atalanta. (2012). European Union Naval Force Somalia Operation Atalanta Brochure d'Information. Retrieved from eunavfor. eu/wp.../02/20150120-EU-InformationBooklet-French-layout_final.pdf

Faleg, G. (2019, May 9). Rethinking stabilization efforts in Somalia. Retrieved from https:// www.sipri.org/commentary/blog/2019/ rethinking-stabilization-efforts-somalia

Geiss, R. \& Petrig, A. (2011). Piracy and Armed Robbery at Sea: The Legal Framework for Counter-Piracy Operations in Somalia and the Gulf of Aden. Oxford: Oxford University Press.

Gilpin, R. (2009). Counting the cost of Somali Piracy. Retrieved from https://www. researchgate.net/publication/228435275_ Counting_the_Costs_of_Somali_Piracy_ Working_Paper

Hearn, S. \& Zimmerman, T. (2014), A windom of opportunity for Somalia: Will external actors' peacebuilding frameworks help or hinder effort?. Retrieved from https://cic. nyu.edu/sites/default/files/somalia_pb_ may2014.pdf

Hunter, R. (2008, October 28). Somali pirates living the high life. $B B C$ News. Retrieved from http://news.bbc.co.uk/2/hi/ africa/7650415.stm

Husein, B. M. (2010). The evidence of toxic waste and radioactive wates dumping in Somalia and its impact on the enjoyment of human rights: A case study. In Paper presented at the United Nations Human Right Council (Geneva) 14th Session.

ICC Commercial Crime Services. (2013, January 16). Piracy falls in 2012, but seas off East and West Africa remain dangerous, says IMB. Retrieved from https://www.icc-ccs. org/news/836-piracy-falls-in-2012-butseas-off-east-and-west-africa-remaindangerous-says-imb

International Crisis Group. (2002). Somalia: Countering terrorism in failed state. Retrieved from https://www.crisisgroup. org/africa/horn-africa/somalia/somaliacountering-terrorism-failed-state

International Maritime Organization. (2014). Djibouti Code of Conduct. Retrieved from http://www.imo.org/en/OurWork/ Security/PIU/Documents/DCoC\%20 Newsletter\%20(2015).pdf

International Maritime Organization. (2017). Regional maritime piracy agreement broadened to cover other illicit martime activity. Retrieved from http://www. imo.org/en/MediaCentre/PressBriefings/ Pages/4-DCOC-widened.aspx

Ismunadi, M. (2011, May 1). MV Sinar Kudus kapal pertama RI yang dibajak perompak somalia. Retrieved from http://www. tribunnews.com/nasional/2011/05/01/ mv-sinar-kudus-kapal-pertama-ri-yangdibajak-perompak-somalia

Kao, M.B. (2016). Against a uniform definition of maritime piracy. Maritime Safety and Security Law Journal, 1(3), 1-20. 
Kellerman, M. G. (2011). Somali Piracy: Causes and consequences. Inquiries Journall Student Pulse, 3(09).

Kraska, J. \& Wilson, B. (2009). Combating pirates of the Gulf of Aden: The Djibouti Code and the Somali coast guard. Ocean $\mathcal{E}$ Coastal Management, 52(10) doi:10.1016/j. ocecoaman.2009.07.002

Leslie, M. (2014). Engaging corrupt Somalia [Unpublished master's thesis]. New Zealand: The University of Waikato.

Loubser, H. M. \& Solomon, H. (2014). Responding to state failure in Somalia. Africa Review, 6(1), 1-17. doi:10.1080/0974 4053.2014.883753

Manuel, M., Mckechnie, A.,Wilson, G., \& das Pradhan-Blach, R. (2017). The new deal in Somalia: An independent review of the Somali Compact 2014-2016. Retrieved from https://www.odi.org/sites/odi.org.uk/ files/resource-documents/11466.pdf

Marciniak, K. (2012). International law on piracy and some current challenges related to its definition. Polish Review of International and European Law, 1(3-4). doi: 10.21697/priel.2012.1.3.04

Martinez-Zarzoso, I. \& Bensassi, S. (2013). The price of modern maritime piracy. Defence and Peace Economics, 24(5), 397-418. doi: 10.1080/10242694.2012.723156

Menkhaus, K. (2004). Vicious circles and the security development nexus in Somalia. Conflict, Security \& Development, 4(2), 149-165. doi: 10.1080/1467880042000259086

Menkhaus, K. (2007). Governance without Government in Somalia. International Security, 31(3), 74-106. doi: 10.1162/ isec.2007.31.3.74

Menkhaus, K. (2010). Stabilisation and humanitarian access in a collapsed state: The Somali case. Disasters, 34(3), 320-341. doi: 10.1111/j.1467-7717.2010.01204.x

Menzel, A. (2018). Institutional adoption and maritime crime governance: The Djibouti code of conduct. Journal of the Indian Ocean Region, 1-19, doi: 10.1080/19480881.2018.1467360

Muli D. (2011). Djibouti code of conduct: An instrument to suppress piracy in the Western Indian Ocean and the Gulf of Aden. World Maritime University Dissertations. 1-160. Retrieved from https:// commons.wmu.se/cgi/view content. cgi?article $=1159 \&$ context $=$ all_dissertations

Murphy, M. (2008) Small boats, weak states, dirty money: Piracy and maritime terrorism in the modern world. New York: Columbia UP.

Nelson E. S. (2012). Maritime terrorism and piracy: Existing and potential threats. Global Security Studies, 3(1), 15-28.

Oceans Beyond Piracy. [n.d.]. Contact group on Piracy off the coast of Somalia (CGPCS). Retrieved from http:// oceansbeyond piracy.org/matrix/contactgroup-piracy-coast-somalia-cgpcs

OECD. (2018). Money laundering. Retrieved from https://www.oecd.org/cleangovbiz/ toolkit/moneylaundering.htm

Osei-Tutu, J. A. (2011). The root causes of the Somali piracy. KAIPTC, $31,1-19$. Retrieved from https://www.africaportal. org/publications/the-root-causes-of-thesomali-piracy/

Osman, F. (2018, June 4). The role of civil society in Somalia's reconstruction: achievements, challenges and opportunities. Retrieved from https://www.saferworld.org.uk/ resources/news-and-analysis/post/775the-role-of-civil-society-in-somaliaasreconstruction-achievements-challengesand-opportunities

Patinkin, J. (2017, April 9). Somalia's pirates are back in business. Retrieved from http:// foreignpolicy.com/2017/04/09/somaliaspirates-are-back-in-business/

Powell, B., Ford, R. \& Nowrasteh, A. (2008). Somalia after state collapse: Chaos or improvement?. Journal of Economic Behavior \& Organization. 67(3-4). doi: 10.1016/j.jebo.2008.04.008 
Raunek, K. (2016, October 13). Causes of maritime piracy in Somalia waters. Retrieved from https://www.marineinsight.com/ marine-piracy-marine/causes-of-piracyin-somalia-waters/

Rothe, D.L. \& Collins, V.E. (2011). Got bandaid? Political discourse, militarized responses, and the Somalia pirate. Contemporary Justice Review, 13(3). doi : 10.1080/10282580.2011.589669

Sengupta, K. \& Howden, D. (2009, April 20). Pirates: The $\$ 80 \mathrm{~m}$ Gulf connection. Retrieved from http://www.independent. co.uk/news/world/africa/pirates-the-80mgulf-connection-1671657.html

Shortland, A. (2012). Treasure mapped: Using satellite imagery to track the developmental effects of Somali piracy. Retrieved from https://www.chathamhouse.org/ sites/default/files/public/Research/ Africa/0112pp_shortland.pdf

Shortland, A., Christopoulou, K. \& Maksatoris, C. (2013). War and famines, peace and light? The economic dynamics of conflict in Somalia 1993-2009. Journal of peace Research, 50(5), 545-561. doi: 10.1177\%2F0022343313492991

Stringer, R. (2016). Food security food overview. In C. Martin. \& J. Coveney (Eds.), Food poverty and insecurity international food inequalities (pp.11-18). Switzerland: Springer International Publishing.

Terefe, H. A. (2012). Discussion Paper, People in crises: tackling the root causes of famines in the Horn of Africa. Retrieved from https://www.researchgate.net/ publication/262388518_People_in_Crises_ Tackling_the_Root_Causes_of_Famine_ in_the_Horn_of_Africa

The World Bank (2018). The World Bank in Somalia. Retrieved from http://www. worldbank.org/en/country/somalia/ overview

Tharoor, I. (2009, April 18). How Somalia's fishermen became pirates. Retrieved from http://content.time.com/time/world/ article/0,8599,1892376,00.html

Tiilikainen, M. \& Mohamed, A.H. (2012). Civil Society in the making: Challenges of the Somali Dispora Organizations, Nordic Journal of Migration Research, 3(1), 40-48. doi: 10.2478/v10202-012-0013-9

Treves, T. (2009). Piracy, law of the sea, and the use of force : developments off the coast of Somalia. The European Journal of International Law, 20(2), 399-414. doi: 10.1093/ejil/chp027

Tsabora, J. (2011). Punishment of international crimes in failed states. African Secuirty Review, 20(3), 67-83. doi: 10.1080/10246029.2011.614064

Tsvetkova, B. (2009). Securitizing piracy off the coast of Somalia. Central European Journal of International \& Security Studies, 3(1), 4463. Retrieved from http://www.cejiss.org/ static/data/uploaded/13835988665123/ Tsvetkova-Piracy_in_Somalia.pdf

UNICEF. (n.d.). Education in Somalia. Retrieved from https://www.unicef.org/somalia/ education.html

UNICEF. (2017). Education in Somalia. Retrieved from https://www.unicef.org/somalia/ education.html

United Nations Convention on the law of the Sea (UNCLOS). (n.d.). United Nations. Retrieved from http://www.un.org/Depts/ los/convention_agreements/texts/unclos/ unclos_e.pdf

United Nations Security Council. (2008, December 16). Resolution 1851 S/RSE/1851. Retrieved from http://www.securitycouncilreport. org/un-documents/document/Somalia\%20 S\%20RES\% 201851.php

United Nations Security Council. (2013, December 31). Report of the SecretaryGeneral on Somalia S/2013/69. United Nations Security Council, 1-21.

United Nations Environmental Programme. (2005, February 25). Somalia: National rapid environmental desk assessment. UNEP Report, 126-137. 
USAID. (2019, August 19). Transition Initiatives for stabilization + $($ TIS +$)$. Retrieved from https://www.usaid.gov/somalia/workingcrises-and-conflict/transition-initiativesfor-stabilization

Warner, R. M. (2013). The prosecution of pirates in National Courts. Abu Dhabi: The Emirates Center for Strategic Studies and Research. Williams, P., D' Alessandro, M., Darkwa, L., de Conning, C., Helal, A., \& Machakaire,J. (2018). Assesing the effectiveness of the
African Union in Somalia/AMISOM, EPON. Retrieved from https://effectivepeaceops. net/amisom/

World Bank Group. (2019). Somalia Economic Update. Retrieved from http:// documents.worldbank.org/curated/ en/811231567610111001/pdf/SomaliaEconomic-Update-Fourth-EditionBuilding-Education-to-Boost-HumanCapital.pdf 